\title{
CONVENTIONAL AND GREEN SYNTHESIS UNDER SOLVENT-FREE MICROWAVE IRRADIATION OF 2-(4-(PHENYLDIAZENYL)PHENOXY) ACETIC ACID DERIVATIVES AND THEIR BIOLOGICAL ACTIVITY
}

\author{
GEORGE BRĂTULESCU \\ University of Craiova, Faculty of Sciences, Department of Chemistry, 13 A. I. Cuza Street, 200585, Craiova, Romania
}

*corresponding author: georgebratulescu@yahoo.com

Manuscript received: April 2020

\begin{abstract}
Several 2-(4-(phenyldiazenyl)phenoxy)acetic acid derivatives were prepared by refluxing method in an aqueous medium, and solvent-free and catalyst-free microwave-assisted method. Retrosynthetic approaches and structural analysis of the target compounds were performed. Spectral characterization (IR, ${ }^{1} \mathrm{H}$ NMR, ${ }^{13} \mathrm{C}$ NMR) is reported. The antibacterial activity of the products was tested, the strongest effect being against $S$. aureus.
\end{abstract}

\section{Rezumat}

În acest articol este prezentată obținerea unor derivați ai acidului 2-(4-(fenildiazenil)fenoxi) acetic prin două metode: la reflux în mediu apos, respectiv cu ajutorul microundelor fără solvent și fără catalizator. Compușilor țintă li s-a efectuat analiza retrosintetică și analiza structurală. Produșii au fost caracterizați spectral (IR, RMN- $\left.{ }^{1} \mathrm{H}, \mathrm{RMN}-{ }^{13} \mathrm{C}\right)$. Activitatea antibacteriană a compuşilor a fost testată, efectul cel mai puternic fiind față de $S$. aureus.

Keywords: 2-(4-(phenyldiazenyl)phenoxy) acetic acid, microwave, spectroscopic analysis, antibacterial activity

\section{Introduction}

Phenylacetic acid derivatives are valuable compounds having practical uses in varied fields of human activity. Many pharmacological agents such as analgesic [1, 2], hypolipidemic [3], anti-inflammatory [2, 4], antifungal $[5,6]$, antibacterial $[7,8]$ and new anticancer agents [9] contain the phenoxy acetic acid scaffold.

Herbicides based on phenoxyacetic acid derivatives are widely used due to the low price and water solubility. In addition, they are easily degradable, biological or photolytic. They are employed in agriculture and on recreational surfaces $[10,11]$.

The use of phenoxyacetic acid derivatives as precursors of side chains plays an important role in industrial biosynthesis of penicillins [12]. The specific production rate of penicillin $\mathrm{V}$ as a function of the phenoxyacetic acid concentration followed Michaelis-Menten-type kinetics. Thus, the higher is the concentration of phenoxyacetic acid, the higher becomes the productivity of penicillin $\mathrm{V}$ [13].

Based on these data, we synthesized some phenoxyacetic acid derivatives with azobenzene skeleton (Figure 1).<smiles>[R]c1cc(OCC(=O)O)ccc1N=Nc1ccc[Y10]([H])c1</smiles>

Figure 1.

Phenoxyacetic acid derivatives with azobenzene scaffold

\section{Materials and Methods}

The substances used are all commercial products from Sigma-Aldrich Chemie GmbH (Steinheim, Germany) and were used without any prior purification. Melting points were measured with the help of a Gallenkamp digital melting point apparatus manufactured by Sanyo Electric Co (Osaka, Japan). IR/FT spectra were recorded with an ALPHA FTIR/ATR spectrometer produced by Bruker Optics GmbH (Ettlingen, Germany). Ultravioletvisible spectra were recorded in $2.5 \times 10^{-4} \mathrm{~mol} / \mathrm{L} 1,4-$ dioxane solution using a Cary $50 \mathrm{UV}$-Vis spectrophotometer manufactured by Varian Inc. (Darmstadt, Germany). A Rohnson P-2012 microwave, manufactured by Rohnson International Limited (Prague, Czech Republic), was employed. A digital infrared IR laser thermometer version 900 -En-00 produced by Shenzhen Jumaoyuan Science and Technology Co. Ltd. (Shenzhen, China), was utilized. ${ }^{1} \mathrm{H}$ NMR spectra were recorded in $\mathrm{CDCl}_{3}$ solution with TMS as internal reference, using a BRUKER ARX 400 spectrometer produced by Bruker Optics GmbH (Ettlingen, Germany), in a magnetic field of induction $\mathrm{B}=9.33 \mathrm{~T}$ (frequency of $400.13 \mathrm{MHz}) .{ }^{13} \mathrm{C}$ NMR spectra were obtained in solution of $\mathrm{CDCl}_{3}$ with TMS as internal reference on a BRUKER ARX 400 spectrometer using a magnetic field with induction $\mathrm{B}=2.34 \mathrm{~T}$ (frequency of 100.62 $\mathrm{MHz})$. The chemical shifts $(\delta)$ were recorded in parts per million (ppm), compared to the internal standard (TMS) and coupling constants $(J)$ in Hz. The following 
standard abbreviations for signal multiplicity were used for the ${ }^{1} \mathrm{H}$ NMR spectra: s (singlet), sbr (broad singlet), d (doublet), t (triplet), q (quartet), spt (septet), $\mathrm{m}$ (multiplet), dd (double doublet), td (triple doublet). The glassware was purchased from BTC Glass Design SRL (Bucharest, Romania). A Vilber Lourmat UV lamp $(\lambda=254 \mathrm{~nm})$ and CN6 darkroom for chromatographic plates fabricated by VILBER LOURMAT Germany $\mathrm{GmbH}$ (Eberhardzell, Germany) was employed. Elemental analyses were accomplished with a Carlo Erba model 1106 elemental analyser fabricated by Carlo Erba SpA (Milano, Italy). A BOECO rotary evaporator RVO 400 SD made by Boeckel Germany GmbH (Hamburg, Germany) was utilized. An Extech EA10 dual input digital thermometer manufactured by Extech Instruments Corporation (Nashua, NH, USA) was employed. Synthesis of intermediates para-hydroxyazobenzene derivatives

Diazotization reaction. To a $100 \mathrm{~mL}$ beaker is added $0.06 \mathrm{~mol}$ of primary aromatic amine in $15 \mathrm{~mL}$ of $\mathrm{H}_{2} \mathrm{O}$. Under magnetic stirring and ice cooling, $16.5 \mathrm{~mL}$ of $32 \% \mathrm{HCl}$ solution $(\mathrm{d}=1.16 ; 0.167 \mathrm{~mol} \mathrm{HCl})$ is added gradually to the initial suspension or emulsion. The resulting mixture is cooled to a temperature below $5^{\circ} \mathrm{C}$. Sodium nitrite $(6,279 \mathrm{~g}, 0.091 \mathrm{~mol})$ is dissolved in water $(16.5 \mathrm{~mL})$, and then this solution is cooled to a temperature below $5^{\circ} \mathrm{C}$ and added dropwise under intense magnetic stirring. During diazotization, the temperature of the medium should not exceed $5^{\circ} \mathrm{C}$. After completion of the addition of aqueous sodium nitrite, the reaction is perfected at the same temperature $\left(\mathrm{T}<5^{\circ} \mathrm{C}\right.$ ) during $45 \mathrm{~min}$. At the end of the reaction, a solution containing the diazonium salt of the amine arose. Urea $(1.3 \mathrm{~g}, 0.021 \mathrm{~mol})$ is added in the solution of diazonium salts and continues stirring for 10 minutes. With starch-iodide paper (it turns blue, if nitrous acid is in excess), the absence of $\mathrm{HNO}_{2}$ is checked (otherwise, more urea is added to destroy nitrous acid).

Coupling reaction. To a $500 \mathrm{~mL}$ beaker with magnetic stirring, we added $210 \mathrm{~mL}$ of $\mathrm{H}_{2} \mathrm{O}, 0.06$ mole of phenol derivative and $14.28 \mathrm{~g}(0.105$ mole $)$ of $\mathrm{CH}_{3} \mathrm{COONa} \mathrm{x}$ $3 \mathrm{H}_{2} \mathrm{O}$. With a $20 \% \mathrm{NaOH}$ solution, the $\mathrm{pH}$ is brought to 11 (at this value the phenols used are completely dissolved). The resulting solution is cooled with ice to a temperature below $5^{\circ} \mathrm{C}$, afterwards the solution cooled with diazonium salt is gradually added. During coupling reaction, the temperature of the reaction medium is strictly maintained below $5^{\circ} \mathrm{C}$. After adding all of the diazonium salt solution, the reaction is kept for 45 minutes at the same temperature. The precipitate formed is filtered off, dried and purified by recrystallization from acetic acid. Using this protocol (a and b) the yield is quite good.

4-(phenyldiazenyl)phenol $(I)$. m.p. $=150-151^{\circ} \mathrm{C}$; Lit. m.p. $=149-151^{\circ} \mathrm{C}[14]$ yield $85 \%$; Anal. Calc. for $\mathrm{C}_{12} \mathrm{H}_{10} \mathrm{~N}_{2} \mathrm{O}$ : $\mathrm{C} 72.72, \mathrm{H} 5.05, \mathrm{~N}$ 14.14. Found: $\mathrm{C}$ 72.68, H 5.00, N 14.08 .

${ }^{1} \mathrm{H}$ NMR $\delta / p p m: 6.92-7.89$ (m, $J=8 \mathrm{~Hz}, 9 \mathrm{H}, \mathrm{H}-$ $4,5,7,8,10,11,12,13,14), 9.21$ (sbr, $1 \mathrm{H}, \mathrm{OH}) ;{ }^{13} \mathrm{C}$ NMR ठ/ppm: 116.2 (C-4, C-8), 129.9 (C-10, C-14), 125.4 (C-5, C-7), 129.2 (C-11, C-13), 130.8 (C-12), 146.7 (C-6), 153.2 (C-9), 161.1 (C-3); IR ( $\left.\mathrm{cm}^{-1}\right)$ : 34003135m, 1505vi, 1488m, 1417i, 1145i, 1108m, 806 $\mathrm{m}$; UV-Vis $(\lambda \mathrm{nm}): 344 \mathrm{~nm}\left(\pi-\pi^{*}\right), 436 \mathrm{~nm}\left(\mathrm{n}-\pi^{*}\right)$. 2-chloro-4-(phenyldiazenyl) phenol (II). m.p. $=85$ $85.5^{\circ} \mathrm{C}$; Lit. m.p. $=84.5-85.5^{\circ} \mathrm{C}[15]$; yield $66 \%$; Anal. Calc. for $\mathrm{C}_{12} \mathrm{H}_{9} \mathrm{~N}_{2} \mathrm{OCl}$ : C 61.93, H 3.87, N 12.04;

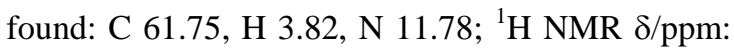
$6.94(\mathrm{~d}, J=8.2 \mathrm{~Hz}, 1 \mathrm{H}, \mathrm{H}-8), 7.41-7.51$ (m, 3H, $\mathrm{H}-11,12,13), 7.60$ (dd, $J=8.2 \mathrm{~Hz}, J=2.0 \mathrm{~Hz}, 1 \mathrm{H}$, H-7), 7.62 - 7.70 (m, 3H, H-5, 10,14), 7.77 (sbr, 1H, $\mathrm{OH}) ;{ }^{13} \mathrm{C}$ NMR $\delta /$ ppm: 117.0 (C-8), 122.1 (C-4), 122.5 (C-10, C-14), 122.9 (C-7), 125.1 (C-5), 129.2 (C-11, C-13), 130.3 (C-12), 143.1 (C-6), 152.7 (C-9), 153.6 (C-3); IR ( $\left.\mathrm{cm}^{-1}\right)$ : 3350-3001m, 1510vi, 1490m, 1418w, $1139 \mathrm{~m}, 1105 \mathrm{w}, 798 \mathrm{~m}$; UV-Vis $(\lambda \mathrm{nm}): 350 \mathrm{~nm}\left(\pi-\pi^{*}\right)$, $440 \mathrm{~nm}\left(\mathrm{n}-\pi^{*}\right)$.

2-allyl-4-(phenyldiazenyl) phenol (III). m.p. $=90$ $91{ }^{\circ} \mathrm{C}$; Lit. m.p. $=89-91$ [16]; yield 74\%). Anal. Calc. for $\mathrm{C}_{14} \mathrm{H}_{12} \mathrm{~N}_{2} \mathrm{O}$ : C 75, H 5.35, N 12.5; found:

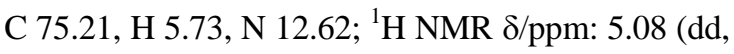
$\left.J=10 \mathrm{~Hz}, J=2.1 \mathrm{~Hz}, 2 \mathrm{H},=\mathrm{CH}_{2}\right), 5.14(\mathrm{dd}, J=16.6$ $\mathrm{Hz}, J=2.1 \mathrm{~Hz}, 2 \mathrm{H}, \mathrm{H}-7,8), 6.08$ (ddt, $J=16.6 \mathrm{~Hz}$, $J=10.1 \mathrm{~Hz}, J=7.7 \mathrm{~Hz}, 1 \mathrm{H},=\mathrm{CH}), 7.03-8.03(\mathrm{~m}$, $6 \mathrm{H}, \mathrm{H}-5,10,11,12,13,14), 9.25$ (sbr, $1 \mathrm{H}, \mathrm{OH}) ;{ }^{13} \mathrm{C}$

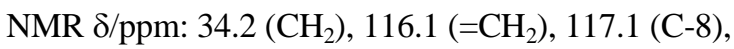
122.5 (C-10, 14), 122.8 (C-7), 124.1 (C-5), 127.2 (C-4), 129.2 (C-11, 13), 130.3 (C-12), 136.7 (=CH), 142.4 (C-6), 152.6 (C-9), 156.1 (C-3); IR ( $\left.\mathrm{cm}^{-1}\right)$ : 3450-3250m, 1638w, 1511i, 1495m, 1416w, 1140w, $1100 \mathrm{~m}, 800 \mathrm{i}$; UV-Vis $(\lambda \mathrm{nm}): 350\left(\pi-\pi^{*}\right), 445\left(\mathrm{n}-\pi^{*}\right)$. 4-(para-tolyldiazenyl) phenol (IV). m.p. $=143-143.5^{\circ} \mathrm{C}$; Lit. m.p. $=143-144^{\circ} \mathrm{C}$ [14]; yield 88\%; Anal. Calc. for $\mathrm{C}_{13} \mathrm{H}_{12} \mathrm{~N}_{2} \mathrm{O}$ : C 73.58, H 5.66, N 13.20; found: $\mathrm{C}$

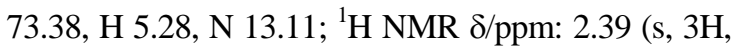
$\left.\mathrm{CH}_{3}\right), 6.93(\mathrm{~d}, J=10 \mathrm{~Hz}, 2 \mathrm{H}, \mathrm{H}-4,8), 7.35$ (d, $J=10$ $\mathrm{Hz}, 2 \mathrm{H}, \mathrm{H}-11,13), 7.72$ (d, $J=10 \mathrm{~Hz}, 2 \mathrm{H}, \mathrm{H}-5,7)$, 7.77 (d, $J=10 \mathrm{~Hz}, 2 \mathrm{H}, \mathrm{H}-10,14), 10.26$ (s, 1H, OH); ${ }^{13} \mathrm{C}$ NMR $\delta / p p m: ~ 21.1\left(\mathrm{CH}_{3}\right), 116.5(\mathrm{C}-4,8), 120.2$ (C-10,14), 125 (C-5,7), 130.5 (C-11, 13), 141 (C-12), 147.1 (C-6), 148.2 (C-9), 161.4 (C-3); IR ( $\left.\mathrm{cm}^{-1}\right)$ : 3421-3997i, 1562i, 1467m, 1412w, 1130m, 987i; UV-Vis $(\lambda \mathrm{nm}): 350\left(\pi-\pi^{*}\right), 447\left(\mathrm{n}-\pi^{*}\right)$.

Conventional synthesis of 2-(4-(phenyldiazenyl)phenoxy)acetic acid derivatives

In a $50 \mathrm{~mL}$ Erlenmeyer flask, it was dissolved chloroacetic acid $(0.472 \mathrm{~g}, 5 \mathrm{mmol})$ in $2.5 \mathrm{~mL}$ of $\mathrm{H}_{2} \mathrm{O}$. Separately, a basic solution is prepared in a $25 \mathrm{~mL}$ Erlenmeyer flask by dissolving $\mathrm{NaOH}(0.4 \mathrm{~g}, 10 \mathrm{mmol})$ in $10 \mathrm{~mL}$ of $\mathrm{H}_{2} \mathrm{O}$. The aqueous chloroacetic acid solution was gradually neutralized with half of the $\mathrm{NaOH}$ solution with stirring and cooling into ice-water bath, ensuring 
that the temperature did not exceed $5^{\circ} \mathrm{C}$. Into $50 \mathrm{~mL}$ round bottom flask, 1-neck, outer joint, size NS 14/23, fitted with an Allihn reflux condenser, socket inner joint, size NS 14/23 and jacket length $40 \mathrm{~cm}$ and magnetic stirrer $5 \mathrm{mmol}$ of aromatic para-hydroxyazo compound was mixed with the other half of the $\mathrm{NaOH}$ solution. After cooling to room temperature, the chloroacetic acid salt solution was poured into the aromatic solution of the para-hydroxyazo compound. The reaction medium was heated to moderate refluxing in a silicone oil bath on a magnetic stirrer hot plate for $3.5 \mathrm{~h}$. The mixture obtained was acidified with a $10 \% \mathrm{HCl}$ solution until $\mathrm{pH}=3$. The resulting precipitate was filtered, dried and purified by recrystallization from acetic acid. The progress of the reaction was tracked by TLC using Merck silica gel $60 \mathrm{~F}_{254}$ plates (eluent, ethanol:benzene $=2: 1)$

Synthesis of 2-(4-(phenyldiazenyl)phenoxy)acetic acid derivatives using microwave irradiation

In a $25 \mathrm{~mL}$ round bottom flask, $\mathrm{NaOH}(0.08 \mathrm{~g}, 2 \mathrm{mmol})$ was mixed with $0.8 \mathrm{~mL} \mathrm{H}_{2} \mathrm{O}$ and stirred until a solution was obtained. In this alkaline solution, 2 mmol of para-hydroxyazo derivative was added and stirred (magnetically) until complete dissolution of the para-hydroxyazo derivative. The water is evaporated under vacuum in a rotary evaporator and sodium azophenate salt brought out. A 50\% concentration solution was prepared by dissolving sodium azophenate salt in acetone and this mixture was poured into a $25 \mathrm{~mL}$ round bottom flask containing sodium chloroacetate $(0.233 \mathrm{~g}, 2 \mathrm{mmol})$. The acetone was removed under vacuum in a rotary evaporator and the resulting mixture was introduced in a $5 \mathrm{~mL}$ microwave-vial. A few drops of $\mathrm{EtOH}$ were added. The resulting paste was irradiated in a microwave reactor $(\lambda=12.2 \mathrm{~cm}$, $400 \mathrm{~W}$ ) for required time. The mixture was poured into a $50 \mathrm{~mL}$ Berzelius beaker containing $30 \mathrm{~mL}$ of $\mathrm{H}_{2} \mathrm{O}$ and $10 \% \mathrm{HCl}$ solution was added until $\mathrm{pH}=3$. The resulting precipitate is filtered, dried and purified by recrystallization from $\mathrm{CH}_{3} \mathrm{COOH}$.

2-(4-(phenyldiazenyl) phenoxy) acetic acid $(V)$. m.p. = $225^{\circ} \mathrm{C}$; yield $48 \%$ (conventional synthesis) and $90 \%$ (microwave synthesis, $5 \mathrm{~min}$.); Anal. Calc. for $\mathrm{C}_{14} \mathrm{H}_{12} \mathrm{~N}_{2} \mathrm{O}_{3}$ : C 65.62, H 4.68, N 10.93; found: C 65.59, H 4.57, N 10.33; ${ }^{1} \mathrm{H}$ NMR $\delta / p p m: ~ 4.73$ (s, $2 \mathrm{H}, \mathrm{CH}_{2}$ ), 7.40 - 7.48 $(\mathrm{m}, J=8 \mathrm{~Hz}, 4 \mathrm{H}, \mathrm{H}-4,8,11,13), 7.83-7.86(\mathrm{~m}, 5 \mathrm{H}$, $\mathrm{H}-5,7,10,12,14), 11.4$ (sbr, $1 \mathrm{H}, \mathrm{COOH}) ;{ }^{13} \mathrm{C}$ NMR S/ppm: 65.2 (C-2), 115.4 (C-4,8), 122.5 (C-10,14), 123 (C 5,7), 129.2 (C-11,13), 130.4 (C-12), 146.9 (C-6), 152.2 (C-9), 158.7 (C-3), 170.1 (C-1); IR $\left(\mathrm{cm}^{-1}\right)$ : 3455-3360m, 1734i, 1617i, 1591i, 1499i, 1428i, 1377w, 1250vi, 1153i, 1087i, 848i; UV-Vis $(\lambda \mathrm{nm}): 238\left(\pi-\pi^{*}\right)$, $350\left(\mathrm{n}-\pi^{*}\right), 440\left(\mathrm{n}-\pi^{*}\right)$.

2-(2-chloro-4-(phenyldiazenyl)phenoxy)acetic acid (VI). m.p. $=134-135^{\circ} \mathrm{C}$; yield $47 \%$ (conventional synthesis) and $81 \%$ (microwave synthesis, $6 \mathrm{~min}$.); Anal. Calc. for $\mathrm{C}_{14} \mathrm{H}_{11} \mathrm{ClN}_{2} \mathrm{O}_{3}: \mathrm{C}$ 57.83, H 3.78, N 9.63; found: C 57.67, H 3.71, N 9.52; ${ }^{1} \mathrm{H}$ NMR $\delta / \mathrm{ppm}: 4.75$

(s, $\left.2 \mathrm{H}, \mathrm{CH}_{2}\right), 7.06(\mathrm{~d}, J=7.6 \mathrm{~Hz}, 1 \mathrm{H}, \mathrm{H}-8), 7.51-7.39$ (m, 2H, H-11,13), $7.60(\mathrm{dd}, J=7.6, J=2.2 \mathrm{~Hz}, 1 \mathrm{H}$, $\mathrm{H}-12), 7.66(\mathrm{~d}, J=2.3 \mathrm{~Hz}, 1 \mathrm{H}, \mathrm{H}-7), 7.72-7.68$ (m, 3H, H-5,10,14); 11 (sbr, $1 \mathrm{H}, \mathrm{COOH}) ;{ }^{13} \mathrm{C}$ NMR 6/ppm: 65.2 (C-2), 114.7 (C-8), 121.2 (C-7), 122.4 (C-10,14), 124 (C-4), 124.3 (C-5), 129.1 (C-11,13), 130.2 (C-12), 145.6 (C-6), 152.6 (C-9), 155.3 (C-3), 169.5 (C-1); IR $\left(\mathrm{cm}^{-1}\right): 3470-3350,1733,1588,1414$, 1262,1039, 875; UV-Vis $(\lambda \mathrm{nm}): 241\left(\pi-\pi^{*}\right), 349$ $\left(\mathrm{n}-\pi^{*}\right), 439\left(\mathrm{n}-\pi^{*}\right)$.

2-(2-allyl-4-(phenyldiazenyl)phenoxy)acetic acid $(V I I)$. m.p. $=82-83^{\circ} \mathrm{C}$; yield $43 \%$ (conventional synthesis) and $78 \%$ (microwave synthesis, $5 \mathrm{~min}$.); Anal. Calc. for $\mathrm{C}_{17} \mathrm{H}_{16} \mathrm{~N}_{2} \mathrm{O}_{3}$ : C 68.91, H 5.40, N 9.45 found: $\mathrm{C} 68.88, \mathrm{H} 5.35, \mathrm{~N} 9.39 ;{ }^{1} \mathrm{H}$ NMR $\delta / \mathrm{ppm}$ : $4.69\left(\mathrm{~s}, 2 \mathrm{H}, \mathrm{CH}_{2}\right), 5.07$ (dd, $J=10 \mathrm{~Hz}, J=2.1 \mathrm{~Hz}, 2 \mathrm{H}$, $\left.=\mathrm{CH}_{2}\right), 5.14(\mathrm{dd}, J=16.6 \mathrm{~Hz}, J=2.1 \mathrm{~Hz}, 2 \mathrm{H}, \mathrm{H}-7,8)$, 6.09 (ddt, $J=16.6 \mathrm{~Hz}, J=10.1 \mathrm{~Hz}, J=7.7 \mathrm{~Hz}, 1 \mathrm{H}$, $=\mathrm{CH}), 8.02-7.04(\mathrm{~m}, 6 \mathrm{H}, \mathrm{H}-5,10,11,12,13,14), 11.8$ (sbr, 1H, COOH) ${ }^{13} \mathrm{C}$ NMR $\delta / p p m: ~ 66.3(\mathrm{C}-2), 114.5$ $\left(=\mathrm{CH}_{2}\right), 116.2(\mathrm{C}-8), 121.2(\mathrm{C}-5), 122.7(\mathrm{C}-10,14)$, 123.2 (C-7), 127.2 (C-4), 129.1(C-11, 13), 130.3 (C-12), 136.6 (=CH), 144.7 (C-6), 152.8 (C-9), 157.2 (C-3), 171.6 (C-1); IR $\left(\mathrm{cm}^{-1}\right)$ : 3460-3330m, 1730vi, $1569 \mathrm{~m}, 1590 \mathrm{i}, 1416 \mathrm{i}, 1270 \mathrm{vi}, 1060 \mathrm{i}, 863 \mathrm{~m}$; UV-Vis $(\lambda \mathrm{nm}): 231\left(\pi-\pi^{*}\right), 351\left(\mathrm{n}-\pi^{*}\right), 451\left(\mathrm{n}-\pi^{*}\right)$.

2-(4-(para-tolyldiazenyl)phenoxy)acetic acid (VIII). m.p. $=217^{\circ} \mathrm{C}$; yield $42 \%$ (conventional synthesis) and $85 \%$ (microwave synthesis, 6 min.); Anal. Calc. for $\mathrm{C}_{15} \mathrm{H}_{14} \mathrm{~N}_{2} \mathrm{O}_{3}$ : C 66.66, H 5.18, N 10.37 found: $\mathrm{C}$ 66.61, H 5.01, N 10.12; ${ }^{1} \mathrm{H}$ NMR $\delta / \mathrm{ppm}: 4.72$ (s, 2H, $\left.\mathrm{CH}_{2}\right), 2.40\left(\mathrm{~s}, 3 \mathrm{H}, \mathrm{CH}_{3}\right), 7.76(\mathrm{~m}, J=7.8 \mathrm{~Hz}, J=1.2$ $\mathrm{Hz}, 2 \mathrm{H}, \mathrm{H}-4,8)$ ), 7.27 (m, 2H, H-11,13), 7.01 (m, $J=$ $6.6 \mathrm{~Hz}, J=3.6 \mathrm{~Hz}, 2 \mathrm{H}, \mathrm{H}-10,14), 7.27$ (m, 2H, H5,7), 11.5 (sbr, $1 \mathrm{H}, \mathrm{COOH}) ;{ }^{13} \mathrm{C}$ NMR $\delta / \mathrm{ppm}: 21.2$ $\left(\mathrm{CH}_{3}\right), 65.1$ (C-2), 115.4 (C-4,8), 120.1 (C-10,14), 129.8 (C-5,7), 130.5 (C-11,13), 141.2 (C-12), 146.9 (C-6), 148.4 (C-9), 158.7 (C-3), 170.1 (C-1); IR ( $\left.\mathrm{cm}^{-1}\right)$ : 3430-3250m, 3020w, 2914m, 1731i, 1600vi, 1583vi, 1497vi, 1427vi, 1370m, 1240vi, 1143i, 1085i, 830vi; UV-Vis $(\lambda \mathrm{nm}): 233\left(\pi-\pi^{*}\right), 352\left(\mathrm{n}-\pi^{*}\right), 453\left(\mathrm{n}-\pi^{*}\right)$.

\section{Results and Discussion}

Before proceeding to the preparation of the compounds we had to perform a retrosynthetic analysis. In this way, we have identified the synthons and the corresponding commercially available synthetic equivalent (accessible reagents).

Retrosynthetic analysis of the target molecule 2-(4(phenyldiazenyl) phenoxy) acetic acid derivatives showed us two possible pathways ( $\mathrm{A}$ and $\mathrm{B}$ ) for the compound synthesis (Figure 2).

In pathway A for the synthesis of the target molecule, starting reagents are substitute derivatives of phenol. These are nitrosated in the para position, and the 
nitrosophenols etherify with chloracetic acid to paranitrosophenoxyacetic acids. The latter, through a
Miller reaction [17] with primary aromatic amines, form desired products (Figure 3).<smiles>[R]c1cccc(N)c1</smiles>

Figure 2.

Retrosynthetic analysis of 2-(4-(phenyldiazenyl)phenoxy) acetic acid derivatives
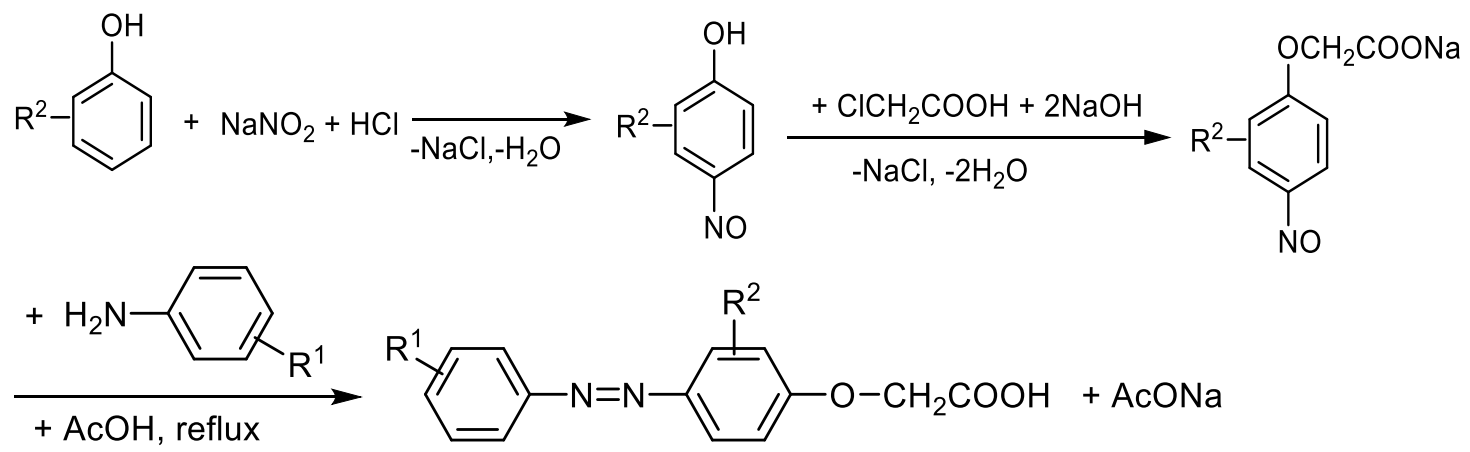

Figure 3.

Synthesis of 2-(4-(phenyldiazenyl)phenoxy) acetic acid derivatives from phenols

In path $\mathrm{B}$, starting reagents are the primary aromatic amines that are converted into diazonium salts. These are coupled by an electrophilic substitution with phenols generating hydroxyazo dyes. Etherification of the latter with chloroacetic acid will lead to the wished products (Figure 4).

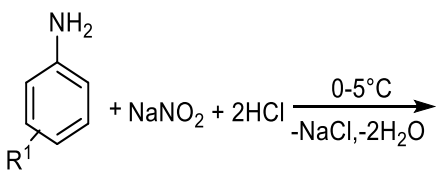<smiles>[R]c1ccc(C)c(O)c1</smiles><smiles>[R]c1ccc(N=Nc2ccc(O)cc2[R])cc1</smiles>

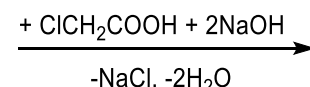

I: $R^{1}=R^{2}=H$

II: $\mathrm{R}^{1}=\mathrm{H} ; \mathrm{R}^{2}=2-\mathrm{Cl}$

III: $\mathrm{R}^{1}=\mathrm{H} ; \mathrm{R}^{2}=2-$ Allyl

IV: $\mathrm{R}^{1}=\mathrm{H} ; \mathrm{R}^{2}=2-\mathrm{Br}$

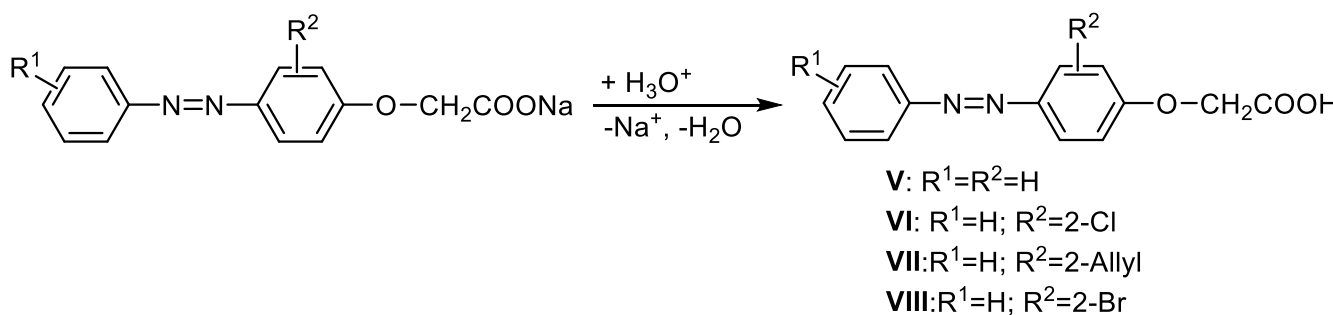

Figure 4.

Synthesis of 2-(4-(phenyldiazenyl)phenoxy) acetic acid derivatives from primary aromatic amines

From the two variants of preparation of the compounds we chose path B (Figure 4), accessibility to reagents being one of the reasons. Azophenols (compounds I, II, III and IV) were prepared in two stages: diazotization and azo coupling reaction. Both steps are carried out in an aqueous medium. In order to avoid the decomposition of the diazonium cation, the temperature must be strictly controlled with a dual digital thermocouple thermometer Extech EA10. The yield of azophenol synthesis varies from $66 \%$ to $88 \%$ (4-(para-tolyldiazenyl) phenol, IV). Obtaining the 2-(4-(phenyldiazenyl)phenoxy) acetic acid derivatives 
was performed by the classical method of refluxing the reaction medium and by microwave assisted synthesis. Four products were obtained using the two techniques (V, VI, VII and VIII). Compounds prepared by reflux method are obtained with yields between $42 \%$ and $48 \%$ for $3.5 \mathrm{~h}$ reaction time. The reaction is carried out in basic aqueous solution. Under these conditions, the hydroxyl anion is capable of causing the hydrolysis of chlorine from chloroacetic acid and thus reduces significantly the yield of the synthesis.

Synthesis of compounds carried out in heterogeneous environment, without solvent, using microwaves is advantageous [18, 19]. Previously, we have shown that in these conditions, inside the reaction medium, there are catalytic centres around which the chemical reaction develops [20, 21]. We applied these findings to the synthesis of our compounds. The reaction medium consists of sodium azophenate and sodium chloroacetate. The reaction medium is highly polar and easily absorbs electromagnetic microwaves. Furthermore, the absence of hydroxyl ions prevents the hydrolysis reaction of chlorine from sodium chloroacetate. The reaction time becomes of the order of the minutes, and the yield of the 2-(4-(phenyldiazenyl)phenoxy) acetic acid derivative synthesis increases significantly. 2-(4- (phenyldiazenyl)phenoxy) acetic acid (V) was obtained with a yield of $90 \%$ during 5 min. of irradiation. The synthesis method implemented is superior to the other methods, both in terms of duration and yield [3]. Both the chemical structures of the intermediate azophenols (I to IV) and the 2-(4-(phenyldiazenyl)phenoxy) acetic acid derivatives ( $\mathbf{V}$ to VIII) were confirmed by spectroscopic measurements (see the synthesis of compounds).

Antibacterial assay

The antibacterial activity of the compounds was tested against two gram-positive bacterium Staphylococcus aureus and Streptococcus pyogenes and two gramnegative bacteria Escherichia coli and Salmonella enteritidis. The antibacterial test was performed using disk diffusion assay - Kirby Bauer method [22]. The reference antibiotic was chloramphenicol.

Compounds were dissolved in aqueous solutions of $0.15 \%$ concentration. As microbiological growth medium, the Mueller-Hinton agar $(20 \mathrm{~mL})$ was used in the Petri dishes (9 $\mathrm{cm}$ diameter). Mueller Hinton agar has a solidifying agent, agar powder that causes the medium solidify at room temperature. Therefore, after solidification at room temperature, the Petri dishes are incubated at $37^{\circ} \mathrm{C}$ for 30 minutes to take out excess moisture. Sterile filter paper discs (measuring $6 \mathrm{~mm}$ in diameter) containing the concentrations of the compounds are placed at equal distances on the agar plate. Aerobic incubation of Petri dishes lasts for 24 hours at $37^{\circ} \mathrm{C}$, and then the diameter of the inhibition zones is measured.

The relative percentage of inhibition relative to chloramphenicol was calculated with the help of the following relation [23]:

$$
P=\frac{\left(S_{1}-S_{2}\right)}{S_{3}-S_{2}} \times 100 \%,
$$

where: $\mathrm{P}$, relative percentage inhibition of the test sample; $S_{1}\left[\mathrm{~mm}^{2}\right]$, surface of inhibition of the tested compound; $S_{2}\left[\mathrm{~mm}^{2}\right]$, surface of inhibition of the solvent, $\mathrm{S}_{3}\left[\mathrm{~mm}^{2}\right]$, surface of inhibition of the standard drug. The surfaces were calculated using the circle area formula, $\pi r^{2}$, where $r$ is the radius of inhibition zone.

Table I

Antimicrobial activity of 2-(4-(para-tolyldiazenyl)phenoxy)acetic acids

\begin{tabular}{|l|c|c|c|c|}
\hline \multirow{2}{*}{ Compound } & \multicolumn{4}{|c|}{ Relative percentage inhibition, P[\%] } \\
\cline { 2 - 5 } & Staphylococcus aureus & Streptococcus pyogenes & Escherichia coli & Salmonella enteritidis \\
\hline V & 50 & 0 & 35 & 1 \\
\hline VI & 59 & 0 & 40 & 0 \\
\hline VII & 65 & 0 & 44 & 7 \\
\hline VIII & 70 & 0 & 52 & 10 \\
\hline
\end{tabular}

The test results show that 2-(4-(para-tolyldiazenyl)phenoxy) acetic acid derivatives have antibacterial activity. The highly active antibacterial compounds contain a carboxyl group, as well as aliphatic chains in their structure. The most potent antibacterial agent is 2-(4-(para-tolyldiazenyl)phenoxy) acetic acid (VIII), the percentage of effective inhibition being $70 \%$ against Staphylococcus aureus (Table I). This suggests that the possibility of making intramolecular hydrogen bonding is probably essential to the interaction of these molecules with the microorganism cell. None of the compounds has any action against Streptococcus pyogenes.
Regarding the mechanism of action of the 2-(4(para-tolyldiazenyl)phenoxy) acetic acid derivatives we can assume that it is similar to the phenoxyacetic acid derivatives. The following biochemical processes are possible [24]: a) the compound damage the cell membrane of the bacterium; $b$ ) the compound interfere with the cellular metabolism in the biochemical processes in which acetylcoenzyme A (acetyl-CoA) participates; c) decoupling oxidative phosphorylation reactions as a consequence of intracellular membrane disruption by the compound and the interference of compounds in cellular metabolism.

Another mechanism to consider is the induction of cell death [25]. The compound produces a mitochondrial 
transmembrane disturbance, inhibiting the oxidative dephosphorylation reaction. These cause a decrease in the concentration of ATP in the mitochondria. Moreover, by opening permeability transition pores, cytochrome $\mathrm{C}$ is released which activates the caspases by forming complexes with the activating factor of the apoptotic protease and triggering cell apoptosis (Figure 5).

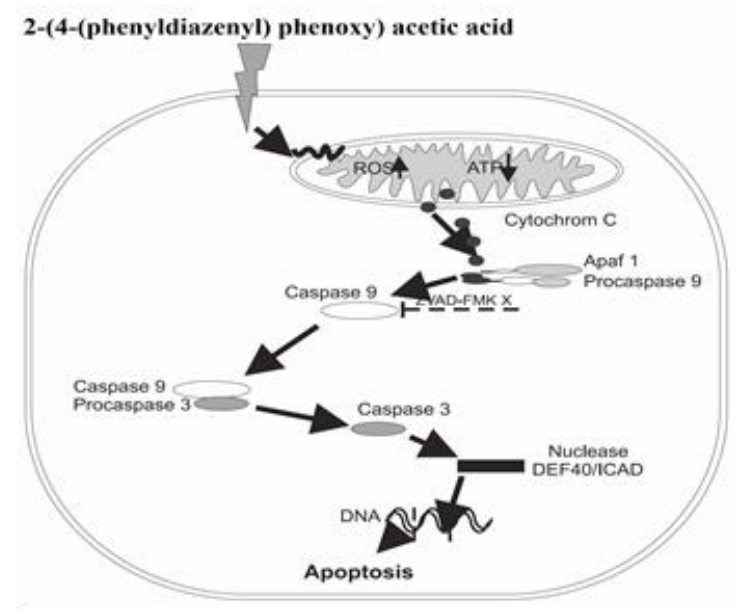

Figure 5.

Possible mechanism of action of 2-(4-(paratolyldiazenyl)phenoxy) acetic acid derivatives [26]

\section{Conclusions}

The derivatives of 2-(4-(para-tolyldiazenyl)phenoxy) acetic acid were synthesized by the conventional method and with the help of microwaves. The syntheses performed under microwaves are green, eco-friendly, easy to achieve, and take place in a short time with high efficiency.

Compounds were biologically evaluated as antibacterial agents against some Gram-positive and Gram-negative bacteria. Biological activity is much more intense against Gram-positive bacteria.

\section{Conflict of interest}

The authors declare no conflict of interest.

\section{References}

1. Sato S, Komoto T, Kanamaru Y, Kawamoto N, Okada, T, Kaiho T, Mogi K, Morimoto S, Umehara N, Koda T, Miyashita A, Sakamoto T, Niino Y, Oka T, New $\mu$-opioid receptor agonists with phenoxyacetic acid moiety. Chem Pharm Bull., 2002; 50(2): 292-297.

2. Gamaniel K, Samuel BB, Kapu DS, Samson A, Wagner H, Okogun JI, Wambebe C, Anti-sickling, analgesic and anti-inflammatory properties of 3,5dimethoxy-4-hydroxy benzoic acid and 2,3,4trihydroxyacetophenone. Phytomedicine, 2000; 7(2): 105-110.

3. Santosh NM, Manjusha CN, Nikhil SS, Pritam ND, Vishakha RS, Swati AB, Synthesis and in vivo hypolipidemic activity of some novel substituted phenyl isoxazol phenoxy acetic acid derivatives. Bioorg Med Chem Lett., 2014; 24(9): 2155-2158.

4. Wille JJ, Kydonieus A, Kalish RS, Inhibition of irritation and contact hypersensitivity by phenoxyacetic acid methyl ester in mice. Skin Pharmacol Physiol., 2000; 13(2): 65-74.

5. Gu HB, Wang ZY, Chen WY, Copper (II) complexes bearing 2-amino benzothiazole and phenoxyacetic acid derivatives: Coordination modes and antimicrobial activity. Chinese J Inorg Chem., 2012; 28(3): 591-600.

6. Patel MR, Colah BR, In vitro antituberculosis and antifungal activity of para - (2-substituted-4-thiazolyl) phenylacetic and para-(2-substituted-4-thiazolyl) phenoxyacetic acids. Bull Haffkine, 1977; 5(2): 72-74.

7. Ciftci E, Beytur M, Calapoglu M, Gursoy-Kol O, Alkan M, Togay VA, Manap S, Yuksek H, Synthesis, characterization, antioxidant and antimicrobial activities and DNA damage of some novel 2-[3-alkyl(aryl)4,5-dihydro-1H-1,2,4-triazol-5-one-4-yl]-phenoxyacetic acids in human lymphocytes. Res $J$ Pharm Biol Chem Sci., 2018; 9(5): 1760-1771.

8. Amjid I, Hamid LS, Ashraf CM, Ahmad M, Weaver GW, Synthesis, characterization and antibacterial activity of azomethine derivatives derived from 2formylphenoxyacetic acid. Molecules, 2007; 12(2): 245-254.

9. Sabatino L, Ziccardi P, Cerchia C, Muccillo L, Piemontese L, Loiodice F, Colantuoni V, Lupo A, Lavecchia A, Chiral phenoxyacetic acid analogues inhibit colon cancer cell proliferation acting as PPAR $\gamma$ partial agonists. Sci Rep., 2019; 9: 5434: 1-12.

10. Zhang H, Song T, Zhang W, Hua W, Pan C, Retention behavior of phenoxyacetic herbicides on a molecularly imprinted polymer with phenoxyacetic acid as a dummy template molecule. Bioorg Med Chem., 2007; 15(18): 6089-6095.

11. McManus SH, Moloney M, Richards KG, Coxon CE, Danaher M, Determination and occurrence of phenoxyacetic acid herbicides and their transformation products in groundwater using ultra high performance liquid chromatography coupled to tandem mass spectrometry. Molecules, 2014; 19(12): 20627-20649.

12. Eriksen SH, Jensen B, Schneider I, Kaasgaard S, Olsen J, Utilization of side-chain precursors for penicillin biosynthesis in a high-producing strain of Penicillium chrysogenum. Appl Microbiol Biotechnol., 1994; 40(6): 883-887.

13. Henriksen CM, Nielsen J, Villadsen J, High exogenous concentrations of phenoxyacetic acid are crucial for a high penicillin $\mathrm{V}$ productivity in Penicillium chrysogenum. Microbiology, 1988; 144(7): 2001-2006.

14. Zomorodian K, Khabnadideh S, Sakhteman A, Mirjalili BBF, Ranjbar M, Zamani L, Synthesis and antifungal activity of benzoxazole derivatives with their SAR analysis by SAS-MAP. Farmacia, 2020; 68(1): 155163.

15. Gaspari J, Gemzova I, Snobl D, Identification of organic compounds LIX. Investigation of the relationship between the structure and the chromatographic behaviour of water - insoluble azo dyes. Collect Czech Chem Commun., 1966; 31(4): 1712-1741, (available in German).

16. Menek N, Basaran, S, Turgut G, Odabasoglu M, Polarographic and voltammetric investigation of 3- 
allyl-4-hydroxyazobenzene. Dyes Pigments, 2004; 61(1): 85-91.

17. Merino E, Synthesis of azobenzenes: the coloured pieces of molecular materials. Chem Soc Rev., 2011; 40(7): 3835-3853.

18. Brătulescu G, Organic chemistry. Unconventional methods. Ed. Sitech, Craiova, 2008; 120, available in Romanian.

19. Brătulescu G, Thèse d'Habilitation à Diriger des Recherches, Université Paul Sabatier, 2018; 30, available in French.

20. Brătulescu G, A new and efficient one-pot synthesis of indoles. Tetrahedron Lett., 2008; 49(6): 984-986.

21. Brătulescu G, 9-Alkylacridine synthesis using 2,2dimetoxypropane as water scavenger. Heterocycles, 2014; 89(8): 1877-1884.

22. Barry AL, Coyle MB, Thornsberry C, Gerlach EH, Hawkinson RW, Methods of measuring zones of inhibition with the Bauer-Kirby disk susceptibility test. J Clin Microbiol., 1979; 10(6): 885-889.

23. Kumar KA, Rai KML, Umesha KB, Evaluation of antibacterial activity of 3,5-dicyano-4,6-diaryl-4ethoxycarbonyl-piperid-2-ones. J Pharm Biomed Anal., 2002; 27(5): 837-840.

24. Bradberry SM, Watt BE, Proudfoot AT, Vale JA, Mechanisms of toxicity, clinical features, and management of acute chlorophenoxy herbicide poisoning: a review. Clin Toxicol (Phila.), 2000; 38(2): 111-122.

25. Tanouchi Y, Lee AJ, Meredith H, You L, Programmed cell death in bacteria and implications for antibiotic therapy. Trends Microbiol., 2013; 21(6): 265-270.

26. Bukowska B, Toxicity of 2,4-dichlorophenoxyacetic acid-molecular mechanisms. Polish J Environ Stud., 2006; 15(3): 365-374 